\title{
Pengaruh Penguasaan Kosa Kata dan Tata Bahasa terhadap Kemampuan Menulis Teks Eksposisi
}

\author{
Neni Kurniati \\ Fakultas Pascasarjana, Universitas Indraprasta PGRI \\ Jalan Nangka No. 58 C/TB. Simatupang, Tanjung Barat, Jakarta Selatan 12530 \\ neni_k@rocketmail.com
}

\begin{abstract}
The purpose of this study was to determine the effect of vocabulary mastery on the ability to write exposition text. To determine the effect of grammar mastery on the ability to write exposition text, and to determine the effect of mastery of vocabulary and grammar together on the ability to write exposition text. The research method used is the survey method. A sample of 88 students was randomly selected from all state junior high school students in Serang city. Data collection is done by conducting a test directly to the sample. For the vocabulary and grammar mastery test using a multiple-choice instrument or multiple-choice test, while the exposition text writing ability test uses a written description test. The results of the study showed: 1) there was a significant effect of mastery of vocabulary and grammar together on the ability to write text exposition of Serang city junior high school students. This is evidenced by the acquisition of sig values $0,000<0,05$ and $\mathrm{Fh}=15,056$. Together the mastery of vocabulary and grammar contributed $26.2 \%$ to the variable ability to write exposition text. 2) there is a significant effect of vocabulary mastery on the ability to write text exposition in Serang city-state junior high school students. This is evidenced by the acquisition of the sig value. $0,000<0,05$ and th $=4,008$. The Vocabulary mastery variable contributed $17.5 \%$ in improving the ability to write exposition text. 3) there is a significant effect of grammar mastery on the ability to write the text of the exposition of Serang city junior high school students. This is evidenced by the value of sig. $0.008<0.005$ and th $=2.733$. Variable grammar mastery contributed $9.14 \%$ in improving the ability to write exposition text.
\end{abstract}

Keywords: vocabulary mastery, grammar, exposition text

\begin{abstract}
Abstrak
Tujuan dari penelitian ini adalah untuk mengetahui pengaruh penguasaan kosakata terhadap kemampuan menulis teks eksposisi. Untuk mengetahui pengaruh penguasaan tata bahasa terhadap kemampuan menulis teks eksposisi, dan untuk mengetahui pengaruh penguasaan kosakata dan tata bahasa secara bersama-sama terhadap kemampuan menulis teks eksposisi. Metode penelitian yang digunakan adalah metode survei. Sampel sebanyak 88 orang siswa yang dipilih secara acak/random dari seluruh siswa smp negeri dikota Serang. Pengumpulan data dilakukan dengan melakukan test langsung kepada sampel. Untuk tes penguasaan kosakata dan tata bahasa menggunakan instrumen multiple choice atau tes pilihan ganda, sedangkan tes kemampuan menulis teks eksposisi menggunakan tes uraian tertulis. Hasil penelitian menunjukan: 1) terdapat pengaruh yang signifikan penguasaan kosakata dan tata bahasa secara bersama-sama terhadap kemampuan menulis teks eksposisi siswa smp negeri kota Serang. Hal ini dibuktikan dengan perolehan nilai sig $0,000<0,05$ dan $F_{h}=15,056$. Secara bersama-sama penguasaan kosakata dan tata bahasa memberikan kontribusi sebesar $26,2 \%$ terhadap variable kemampuan menulis teks eksposisi. 2) terdapat pengaruh yang signifikan penguasaan kosakata terhadap kemampuan menulis teks eksposisi siswa smp negeri kota Serang. Hal ini dibuktikan dengan perolehan nilai sig. $0,000<0,05$ dan $t_{h}=4,008$. Variable penguasaan kosakata memberikan kontribusi sebesar $17,5 \%$ dalam meningkatkan kemampuan menulis teks eksposisi. 3) terdapat pengaruh yang signifikan penguasan tata bahasa terhadap kemampuan menulis teks eksposisi siswa smp negeri kota Serang. Hal ini dibuktikan dengan nilai sig. $0,008<0,005$ dan $t_{h}=2,733$. Variable penguasaan tata bahasa memberikan kontribusi sebesar 9,14\% dalam meningkatkan kemampuan menulis teks eksposisi.
\end{abstract}

Kata Kunci: penguasaan kosakata, tata bahasa, teks eksposisi

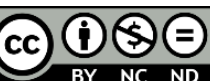

Creative Commons Attribution-NonCommercial-NoDerivatives 4.0 International License 


\section{PENDAHULUAN}

Bahasa merupakan suatu sistem dan sistemis yang digunakan untuk melambangkan pikiran dan perasaan manusia agar dapat menyampaikannya kepada orang lain. Di dalam proses berkomunikasi bahasa merupakan suatu elemen yang sangat penting. Hal ini menunjukkan bahwa tanpa bahasa, komunikasi tidak terjadi dan tidak dapat dilakukan dengan baik begitu pun dengan interaksi sosial. Di dalam proses berkomunikasi antarsesama terdapat beragam tujuan, seperti untuk mendapatkan informasi, untuk menjalin kekerabatan, melakukan transaksi perdagangan, mengungkapkan gagasan dan perasaan kepada orang lain baik lisan ataupun tulisan.

Selanjutnya, pembelajaran bahasa Indonesia di sekolah-sekolah bertujuan agar siswa terampil dalam berbahasa yang meliputi keterampilan menyimak, berbicara, membaca, dan menulis. Keempat keterampilan berbahasa tersebut saling berkaitan satu dengan yang lain. Keterampilan menyimak harus dikuasai karena dengan kegiatan menyimak, seseorang dapat mengenal bunyi-bunyi yang membedakan arti, memeroleh kosakata, dan mengetahui gramatikal. Keterampilan berbicara juga dikuasai seseorang melalui kegiatan menyimak lewat pengenalan bunyi-bunyi serta kosakata dan tata bahasa. Keterampilan membaca harus dimiliki oleh setiap orang, karena melalui membaca seseorang memeroleh kosakata baru yang membantu memperkaya perbendaharaan kosakatanya. Dari keempat keterampilan berbahasa tersebut, keterampilan menulis merupakan proses paling akhir yang menuntut kemampuan berpikir. Kesulitan menulis selalu menjadi masalah bagi semua orang. Keterampilan menulis sangat penting bagi semua elemen pendidikan seperti pelajar, mahasiswa, guru, dan dosen sebagai salah satu alat komunikasi tertulis.

Salah satu tujuan pengajaran keterampilan berbahasa di sekolah ialah agar siswa terampil menulis. Agar siswa terampil menulis maka harus ada peningkatan jumlah penguasaan kosakata. Menurut (Kridalaksana, 2007) kosakata adalah:

a. komponen bahasa yang memuat semua informasi tentang makna pemakaian kata dalam bahasa;

b. kekayaan kata yang dimiliki seorang pembicara, penulis, atau suatu bahasa;

c. daftar kata yang disusun seperti kamus, tetapi dengan penjelasan yang singkat dan praktis.

Hastuti dkk. dalam (Pramudyantoro, 2000) menyebutkan bahwa kosakata atau vokabuler yang disebut juga perbendaharaan kata adalah kata-kata yang terdapat dalam suatu bahasa. Kadang-kadang kosakata diartikan sebagai kata disusun secara alfabetis yang disebut glosari.

Menulis eksposisi bertujuan untuk menyampaikan dan menjelaskan sesuatu kepada para pembaca agar pembaca mengerti atau memahami perihal penjelasan tersebut.Untuk membuat pembaca memahami penjelasan penulis, maka diperlukan adanya komunikasi yang baik melalui kata-kata yang dirangkai menjadi kalimat yang terdapat dalam tulisan tersebut. Untuk dapat berkomunikasi dengan anggota masyarakat yang lain (dalam hal ini pembaca), setiap orang perlu memperluas kosakatanya, perlu mengetahui sebanyak-banyaknya perbendaharaan kata dalam bahasanya (Keraf, 2004). Kosakata merupakan bahan utama untuk merealisasikan ide dan gagasan, sedangkan tata bahasa merupakan seperangkat kaidah kebahasaan 
yang digunakan untuk menyusun kata dan kalimat sehingga menjadi kalimat yang benar menurut kaidah bahasa.

Menurut (Djiwandono, 2011), tata bahasa berkaitan dengan kemampuan tentang kata pada tataran morfologi dan kemampuan tentang kalimat pada tataran sintaksis. Kemampuan tentang kata meliputi pemahaman dan penggunaan kata dan gabungan kata masing-masing dengan bagian bagian yang memiliki arti dan dikenal sebagai morfem, sedangkan kemampuan tentang kalimat meliputi pemahaman dan penyusunan kalimat, baik kalimat tunggal dengan berbagai bentuk dan susunannya, maupun kalimat majemuk dalam berbagai bentuk dan jenis penggabungannya.

Keterampilan menulis merupakan proses paling akhir yang menuntut kemampuan berpikir. Di dalam proses menuangkan gagasan atau berpikir tentu seseorang tidak mungkin menulis secara sembarang. Artinya, seorang penulis memerlukan kemampuan menginterpretasikan gagasannya ke dalam bentuk tulisan yang mudah dipahami pembaca. Pemilihan kosakata yang tepat akan membantu pembaca memahami makna dari tulisan tersebut. Kesulitan menulis selalu menjadi masalah bagi semua orang. Kurangnya latihan menulis di sekolah menyebabkan mereka kesulitan dalam menuangkan gagasannya dalam bentuk tulisan. Salah satu materi keterampilan menulis di SMP kelas 8 adalah menulis teks eksposisi, eksposisi merupakan tulisan paparan atau memberikan informasi kepada pembaca. Kemampuan menulis teks eksposisi sangat besar manfaatnya di era globalisasi seperti sekarang ini (Tim Edukatif, 2017). Eksposisi bertujuan untuk menguraikan suatu pokok pikiran yang dapat memperluas pandangan pembaca. Hal ini berarti bahwa dalam memberikan informasi kepada pembaca, tentu diperlukan kemampuan penguasaan, penggunaan kosakata serta tata bahasa yang baik agar dalam menuliskan pemaparannya mudah untuk dipahami pembaca. Dalam menulis diperlukan adanya suatu bentuk ekspresi gagasan yang berkesinambungan dan mempunyai urutan logis dengan menggunakan kosa kata dan tata bahasa tertentu atau kaidah bahasa yang digunakan sehingga dapat menggambarkan atau dapat menyajikan informasiyang diekspresikan secara jelas (Suriamiharja, Husen, \& Nurjanah, 1996).

\section{METODE}

Berdasarkan jenisnya penelitian ini termasuk penelitian kausal komparatif atau Penelitian ex_post facto. Penelitian kausal komparatif merupakan penelitian di mana variabel-variabel bebas telah terjadi ketika peneliti mulai dengan pengamatan variabel terikat dalam suatu penelitian. Pada penelitian ini keterikatan antar variabel bebas dengan variabel bebas, maupun antar variabel bebas dengan variabel terikat sudah terjadi secara alami dan peneliti dengan setting tersebut ingin melacak kembali jika memungkinkan apa yang menjadi faktor penyebab (Sukardi, 2011). Metode yang digunakan dalam penelitian ini adalah metode survei. Menurut Sasmoko dalam (Hindun, 2017) yang mengatakan bahwa survei adalah pengumpulan data yang relatif terbatas dari kasus-kasus yang relatif besar jumlahnya. Tujuan survei adalah mengumpulkan informasi tentang variabel dan bukan informasi tentang individu. Ada tiga variabel dalam penelitian ini yang terdiri dari 2 variabel bebas (X) dan satu variabel terikat (Y). Variabel bebas

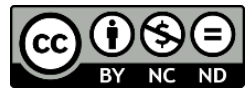


tersebut adalah penguasaan kosakata $\left(\mathrm{X}_{1}\right)$, penguasaan tata bahasa Indonesia $\left(\mathrm{X}_{2}\right)$, sedangkan variabel terikat yaitu kemampuan menulis eksposisi (Y).Variabel bebas adalah variable yang mempengaruhi atau yang menjdi sebab perubahannya atau timbulnya variabel dependen (terikat), sedangkan variabel terikat merupakan variabel yang dipengaruhi karena adanya variabel bebas (Sugiyono, 2008).

Populasi adalah himpunan unit statistik secara keseluruhan (Abdullah, 2014). Populasi dalam penelitian ini adalah seluruh siswa kelas VIII SMP Negeri se-Kota Serang yang berjumlah 880 orang, dengan penjabaran Kota Serang sebanyak 420 populasi, SMPN 16 Kota Serang sebanyak 360 populasi, SMPN Satap Kasemen 100 populasi. Sampel adalah sebagian dari unit-unit yang ada dalam populasi yang ciri-ciri atau karakteristiknya benar-benar diselidiki (Djojosuroto \& Sumaryati, 2000). Beberapa peneliti menyatakan bahwa besarnya dari seluruh populasi yang berjumlah 880 orang, maka diambil 10\% lalu didapatkan hasil SMPN 5 Kota Serang 42 orang, SMPN 16 Kota Serang 36 orang dan SMPN Satap Kasemen 10 orang, maka total sampel 88 orang.

Metode dalam penelitian ini ialah analisis deskriptif, yaitu metode penelittian yang mendeskripsikan data melalui hitungan statistik pada sampel saja atau pada populasi saja (Abdullah, 2014). Untuk mengambil data dari sampel penulis menggunakan alat pengumpul data yaitu tes. Instrumen penelitian dalam penelitian ini berupa tes objektif dan tes tertulis penulisan eksposisi. Instrumen yang berupa tes objektif digunakan untuk mengungkap peguasaan kosakata dan tata bahasa siswa, tulis digunakan untuk mengetahui kemampuan menulis teks eksposisi siswa.

Validitas adalah suatu ukuran yang menunjukkan ukuran kevalidan atau kesahihan suatu instrumen dapat mengukur apa yang bisa diukur (Arikunto, 2009). Untuk mengetahui kualitas butir soal dilakuan pengujian dengan program iteman terlebih dahulu soal diujicobakan pada sejumlah siswa. Kualitas soal tersebut meliputi tingkat kesulitan butir, tingkat daya beda butir dan analisis distraktor. Indeks kesukaran berkisar antara 0.0-1.0, bila indeks kesukaran 0.0 berarti tes tersebut sangat sulit, tetapi jika indeks kesukaran 1.0 berarti soal tersebut sangat mudah (Arikunto, 2009). Menurut (Arikunto, 2009), sebuah butir soal dinyatakan baik atau layak jika memenuhi persyaratan masuk ke dalam interval tertentu. Indeks tingkat kesukaran (ITK) yang dapat diterima dalam penelitian ini adalah berkisar antara P1,00 -0,30 adalah butir soal yang berpredikat sulit, $0.30-0.70$ berpredikat sedang, dan $0.70-1,00$ berpredikat mudah. Indeks daya beda suatu butir soal yang baik menurut Suharsimi adalah yang dapat membedakan siswa pandai dan bodoh dan harus mencapai $0.40-0,70$ (Arikunto, 2009). Butir soal yang indeks daya bedanya kurang dari 0.00 dianggap tidak layak dan perlu direvisi atau diganti. Dalam penelitian ini, indeks daya beda dikatakan baik apabila indeksnya mencapai 0.20 atau lebih. Tes pilihan ganda dalam penelitian ini menggunakan lima alternatif jawaban yaitu A, B, C, D dan E. Kelima alternatif itu hanya ada satu jawaban yang benar. Jadi, empat alternatif jawaban yang lain merupakan pengecoh (distraktor). Suatu pengecoh berfungsi baik apabila pengecoh itu mempunyai daya pikat bagi peserta tes yang kurang memahami konsep (Arikunto, 2009). Uji Realibilitas instrumen dimaksudkan untuk mengetahui apakah instrumen tersebut cukup dapat 
dipercaya sebagai alat pengumpul data sehingga mengungkap data yang bisa dipercaya.

\section{HASIL DAN PEMBAHASAN}

Hasil yag didapat dari penelitian ini adalah nilai yang diperoleh dari 88 orang siswa adalah terendah 62, tertinggi 97 rata-rata 80,51, median 82,00 modus 82 dan simpangan baku 9,344. Jika dilihat dari hasil perhitungan dapat dikatakan bahwa kemampuan menulis teks eksposisi Bahasa Indonesia di Kota Serang tergolongtinggi. Hal ini diindikasikan dengan perolehan skor rata-rata 80,51. Hasil tes penguasaan kosakata dari 88 siswa dihasilkan skor terendah 63, tertinggi 98 skor rata-rata 84,72, median 81,00 modus 83 dan simpangan bku 8,29

Dari hasil ini bisa disimpulkan bahwa penguasaan kosakata siswa SMPN di Kota Serang tergolong tinggi terlihat dari rerata nilai sebesar 84,72, sedangkan dari hasil tes penguasaan Tata bahasa dari 88 orang siswa diperoleh nilai terendah 88 , tertinggi 98 , nilai rerata 82,48, median 83,00 modus 83 dan simapangan baku 8,245. Dari hasil ini dapat disimpulkan bahwa penguasaan tata bahasa siswa SMPN di Kota Serang cukup tinggi. Hal ini diindikasikan dengan perolehan nilai rerata skor penguasaan tata bahasa 82,48. Uji Normalitas data terpenuhi dengan uji normalitas Galat dengan hasil $\mathrm{Z}=0,705$ dan $\mathrm{Sig}=0,704>0,05$. Untuk uji linieritas varibel penguasaan kosakata terhadap kemampuan menulis eksposisi mempunyai hubungan yang linier dengan deviation from linearity $\mathrm{Fo}=1.182$ dan $\mathrm{Sig}=0,318>0,05$, sedangkan variabel penguasaan tata bahasa dengan kemampuan menulis teks eksposisi siswa mempunyai hubungan yang linier dengan Deviation from linearity $\mathrm{Fo}=1,558$ dan $\mathrm{Sig}=0,170>0,05$. Untuk uji hipotesis dari hasil perhitungan Anova satu jalur diperoleh hasil terdapat pengaruh yang signifikan penguasaan kosakata terhadap kemampuan menulis teks eksposisi siswa SMP Negeri kota Serang. Hal ini dibuktikan dengan perolehan nilai sig. 0,000 $<0,05$ dan $\mathrm{t}_{\mathrm{h}}=4,008$. Variable penguasaan kosakata memberikan kontribusi sebesar $26,2 \%$ terhadap kemampuan menulis teks eksposisi. Terdapat pengaruh yang signifikan penguasaan kosakata dan tata bahasa secara bersama-sama terhadap kemampuan menulis teks eksposisi siswa smp negeri kota Serang. Hal ini dibuktikan dengan perolehan nilai sig $0,000<0,05$ dan $F_{h}=15,056$. Secara bersama-sama penguasaan kosakata dan tata bahasa memberikan kontribusi sebesar $17,2 \%$ terhadap variabel kemampuan menulis teks eksposisi. Terdapat pengaruh yang signifikan penguasan tata bahasa terhadap kemampuan menulis teks eksposisi siswa SMP Negeri kota Serang. Hal ini dibuktikan dengan nilai sig. 0,008 $<0,005$ dan $t_{h}=2,733$. Variable penguasaan tata bahasa memberikan kontribusi sebesar 9,14\% dalam meningkatkan kemampuan menulis teks eksposisi.

\section{SIMPULAN}

Terdapat pengaruh yang signifikan penguasaan kosakata dan penguasaan tatabahasa secara bersama-sama terhadap kemampuan menulis eksposisi bahasa Indonesia siswa SMPN di Kota Serang. Hal ini dibuktikan dengan perolehan nilai Sig. $0,000<0,05$ dan $F_{h}=15,056$ dengan kontrbusi sebesar 17,2\% artinya

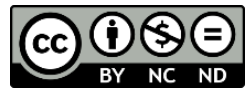


penguasaan kosakata dan tata bahasa memberikan kontribusi yang besar terhadap kemampuan menulis teks eksposisi.siswa smpn di kota Serang.Terdapat pengaruh yang signifikan penguasaan kosakata terhadap kemampuan menulis eksposisi bahasa Indonesia siswa SMPN di Kota Serang. Hal ini dibuktikan dengan perolehan nilai Sig. $0,000<0,05$ dan $t_{h}=4,008$ dan kontribusi sebesar $26,2 \%$ artinya penguasaan kosakata mempunyai kontribusi yang cukup besar terhadap kemampuan menulis teks eksposisi. Terdapat pengaruh yang signifikan penguasaan tatabahasa terhadap kemampuan menulis eksposisi bahasa Indonesia siswa SMPN di Kota Serang. Hal ini dibuktikan dengan perolehan nilai Sig. 0,008 $<0,05$ dan $t_{h}$ $=2,733$ dengan kontribusi sebesar $27,2 \%$ artinya penguasaan tata bahasa mempunyai kontribusi yang cukup besar terhadap kemampuan menulis teks eksposisi siswa smpn dikota Serang. Jadi, dapat disimpulkan bahwa siswa yang penguasaan kosakata dan tata bahasanya bagus akan mampu menyusun teks eksposisi dengan baik.

\section{DAFTAR PUSTAKA}

Abdullah, S. I. (2014). Aplikasi komputer. Jakarta: Pustaka Mandiri.

Arikunto, S. (2009). Dasar-dasar evaluasi pendidikan. Jakarta: Bumi Aksara.

Djiwandono, S. (2011). Tes bahasa: Pegangan bagi pengajar bahasa. Jakarta: Indeks.

Djojosuroto, K., \& Sumaryati, M. L. . (2000). Prinsip-prinsip dasar penelitian bahasa dan sastra. Bandung: Nuansa Cendekia.

Hindun, S. (2017). Pengaruh motivasi belajar dan persepsi atas lingkungan sekolah terhadap prestasi belajar ilmu pengetahuan sosial. Universitas Indraprasta PGRI.

Keraf, G. (2004). Diksi dan gaya bahasa. Jakarta: Gramedia Pustaka Utama.

Kridalaksana, H. (2007). Pembentukan dalam bahasa Indonesia. Jakarta: Gramedia Pustaka Utama.

Pramudyantoro. (2000). Penggunaan kosakata bidang ilmu pengetahuan alam dan teknologi dalam karangan siswa kelas II SMU Muhammadiyah V Yogyakarta. Universitas Negeri Yogyakarta.

Sugiyono. (2008). Metode penelitian kuantitatif kualitatif dan $R \& D$. Bandung: Alfabeta.

Sukardi. (2011). Metodologi penelitian pendidikan kompetensi dan praktiknya. Jakarta: Bumi Aksara.

Suriamiharja, A., Husen, A., \& Nurjanah, N. (1996). Petunjuk Praktis Menulis. In Depdikbud. Jakarta: Depdikbud.

Tim Edukatif. (2017). Kompetensi berbahasa Indonesia untuk kelas X. Yogyakarta: Erlangga. 